\title{
The Relative Importance of Financial Ratios in Making Investment and Credit Decisions in Jordan
}

\author{
Mohammad Ahmad Alqam ${ }^{1}$, Haitham Yousef Ali ${ }^{1} \&$ Yaser Mohd Hamshari ${ }^{1}$ \\ ${ }^{1}$ Accounting Department, College of Administrative and Financial Sciences, Petra University, Amman, Jordan \\ Correspondence: Yaser Mohd Hamshari, Accounting Department, College of Administrative and Financial Sciences, \\ Petra University, Amman, Jordan.
}

Received: September 25, 2020

Accepted: November 4, 2020

Online Published: January 14, 2021

doi:10.5430/ijfr.v12n2p284

URL: https://doi.org/10.5430/ijfr.v12n2p284

\begin{abstract}
This study has aimed to demonstrate the relative importance of financial analysis using ratios for each of lenders and investors in Jordan when making decision.

Also; this study, included the financial ratios that could be adopted by decision makers in the industry (area) of lending or investment. The study included two categories; first is the category of financial intermediaries; to express the category of investors in Amman stock exchange (ASE), while the second category included employees of credit departments -in Jordanian banks- for the category of lenders.

The collection of study data was based on a review of the subject's scientific literature, previous studies and by preparing a questionnaire that was designed on the basis of the theoretical framework of the study and its hypotheses.

The objectives of financial analysis are to judge the efficiency of management and to use the information available to make various administrative decisions. The study found that financial ratios are used by data users when making decisions related to investment and lending. The results of the study also revealed the interest of lenders in debt and liquidity ratios, while investors' attention is focused on profitability and market ratios.
\end{abstract}

Keywords: financial ratios, investment decisions, credit decisions

\section{The General Framework of Study}

\subsection{Introduction}

The business sectors have witnessed a great degree of sophistication and complexity, and in light of the importance of these sectors there had to be a way to help the stakeholders in these sectors to rationalize their decision making regarding lending or investing in these companies. Financial analysis came to present itself as a suitable \& appropriate alternative that would help these parties to make rational decisions about the future of these businesses, and financial ratios are an important means used by the financial analyst to provide decision makers with appropriate information about the financial situation of the companies.

The importance of financial analysis using ratios has increased as an essential tool through which the performance of the establishments can be evaluated and the results of their work can be judged. And the information provided by financial analysis using ratios is used in the process of decision-making, to diagnose their weaknesses and strengths and to predict the economic situation. Financial analysis is no longer limited to the study and analysis of financial statements, but goes beyond the study of accounting and non-accounting information related to enterprises.

Because of the importance of the of financial ratios as a mean of financial analysis, this study came to shed light on how the different categories of financial ratios are used and the relative importance of their use by decision-makers concerning lending and investing in Jordanian companies.

\subsection{The Importance of the Study}

The importance of the study stems from the importance of the subject of the study .The use of ratio analysis has become an important tool in providing different entities with appropriate and reliable information to be used to make rational decisions. Accordingly, we can review the importance of the study through the following points: 
1. The importance of information provided by different financial ratios in rationalizing investment and credit decisions.

2. The subject of financial analysis and its tools is one of the important topics in the accounting and financial arena in Jordan.

3. Increased competition among business sectors highlighted the need for an essential tool that contributes to decision-making, rationalizing them and evaluating companies' performance.

\subsection{The Objectives of the Study}

This study aims to identify the importance of financial analysis using ratios as one of the methods that contribute to decision-making in companies, and the importance of using financial analysis ratios in financial decision-making by investors and lenders.

The objectives of the study can be summarized as follows:

Identifying one of the important financial analysis tools, namely analysis using ratios, and the extent to which they contribute to the decision-making process.

Explain the financial ratios that are used in investment and lending decisions.

Learn about the financial ratios most used in lending and investment decision-making by both lenders and investors.

\subsection{The Determinants of the Study}

This study encountered some limitations that can be summed up as:

Some members of the target study sample are not serious about giving the necessary information for research.

The study is limited to only two categories of influential groups in investment and lending decisions

\subsection{The Problem of the Study}

The problem with the study is the difficulty of making the decision to lend or invest, as this requires appropriate special information to make such decisions, and financial ratios are an essential part of such information and in order for decisions to be rational, the decision-maker must select the appropriate ratios for such decisions. It is possible to summarize the problem of the study by asking the following questions:

1 What are the financial ratios that investors and lenders focus on when making an investment or lending decision?

2 Does the relative importance of the use of financial ratios vary between lenders and investors?

\subsection{The Study Hypotheses}

To solve the problem of study and to achieve its goals were formulated the following hypotheses:

The first hypothesis:

H01: There is no statistically significant effect at the level $(0.05 \geq \alpha)$ for financial analysis ratios in the decision-making of investment for investors.

Hypothesis 2:

H02: There is no statistically significant effect at the level of $(0.05 \geq \alpha)$ of financial analysis ratios in the decision-making of lending to lenders.

\subsection{Study Variables}

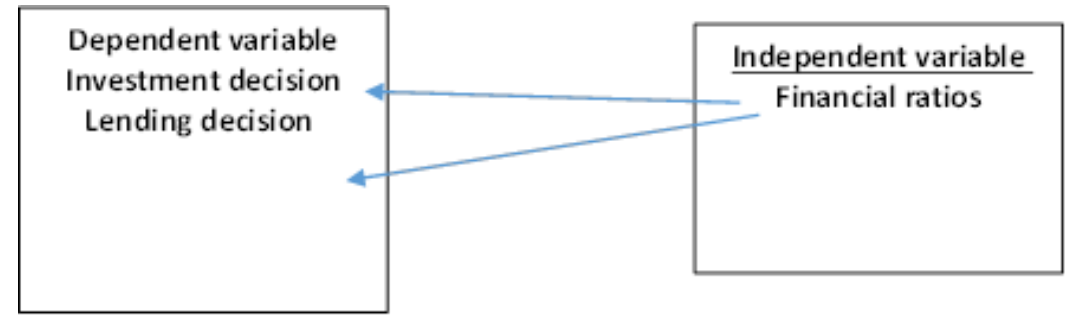

Figure 1. Study model 


\section{Review of Related Literatures}

The study (Fawzi, Muhammad- 2020) found that there is high confidence and confidence in the executive departments of Islamic financial institutions (investment and credit decision makers) through the use of financial analysis tools (financial ratios) to analyze the financial statements and the accounting report. The study also proved that there is a positive relationship between the degree of Reliance on financial analysis tools and the degree of level and efficiency of the scientific and professional performance of financial analysts and the degree of reliance on them in making central decisions, The study (Badarin \&, Shaheen, 2019) also recommended the necessity to focus on the elements of the financial situation of companies and the use of financial analysis tools (financial ratios) according to the nature of the companies 'activity in order to reduce credit risks and ensure the companies' ability to pay their debts on their due date through the ability of financial analysts in banks On the use and interpretation of financial ratios according to the companies' activity and in proportion to their financial position in order to avoid their default in payment, (Al-Sartawi, 2019) study recommended the need to use financial analysis tools in evaluating financial performance to identify weaknesses and strengths and help managers on how to address weaknesses and make the right decisions and monitor the company's activity. The study also found through the study sample that all the companies under study have relied on financial analysis tools to increase the volume of investments and expand in increasing the size of production lines. Several companies also own investments in companies in Europe and East Asia. Also (Barkibeh, 2019) study urged on the need to train managers on financial analysis to make the right decisions through the diagnosis of the status of the establishments using financial analysis with the need to train those managers on how to use financial ratios and their interpretations in order to make the right decision and deal effectively with the results of the financial ratios.As for (Dr. Al-Attar, 2018) study, it recommended the importance of using financial analysis tools, especially when preparing annual budgets, as it was found through the study of the sample that in the companies (pharmaceutical companies) under study, that the ownership percentage is high with the rise in the industry standard for it, knowing that the liquidity ratio of these companies is high, which indicates no need to borrow. (Dr. Habash and Dr. Rayma, 2018) study stated that individual investors in the Amman Financial Market rely on financial tools to make investment decisions. The study also found that many investors are interested in the cash flow list in making investment decisions. Besides, (Sakar, Barakat), 2018) study found that many banks rely on studying loan files and making decisions about financing based on financial ratios, Meantime, many bank employees have high efficiency in using several types of financial ratios in studying financing files. The study also recommended the need to define and distinguish financial ratios according to the nature of the activity and type of the facility in addition to the market in which it operates. The study also recommended the necessity of developing an integrated analytical model based on the most important financial ratios used in banks in order to protect the bank and the client, as it was found from the study sample that the most used ratios in financial analysis are liquidity ratios, which reflect the adequacy of current assets to pay their obligations in the short term. As for (El-Helou, 2016) study, it recommended the necessity of using all financial analysis tools for all client activities and identifying any indicator that may attract the attention of the financial analyst in order to direct the banking management towards proper decision-making based on effective scientific financial analysis. The study also called for the necessity of using financial analysis tools that would show the rate of financial leverage for establishments that need to borrow. The study also mentioned that the interest of the financial analyst in banks on companies that have reasonable liquidity ratios, as for companies that do not have sufficient liquidity, they are granted credit facilities and the researcher prefers the reason for this to the lack of understanding and awareness of bank employees of the importance of financial analysis tools. The researcher urged the necessity of conducting training courses on the importance of financial analysis tools to develop the performance of banks. (Al-Qadi, Al-Shatnawi, and Al-Shukry, 2016) study recommended the necessity of using financial analysis tools in investment and borrowing decisions and the importance of training workers on financial analysis tools in a way that serves investment and borrowing, and to spare banks credit risks as many banks are exposed to credit risks continuously and this is due to the deficiency In understanding, realizing and applying financial analysis tools.

\subsection{Theoretical Framework}

There are several definitions of financial analysis, the most important of which is (Matar, 2016):It is "A process through which a set of quantitative and qualitative indicators about the economic activity of the project is discovered or derived, and contributes to determining the importance and characteristics of the operational and financial activities of the project through information extracted from financial statements and other sources in order to be used then in evaluating the performance of the enterprise in order to make decisions", also (Akl, 2014) defined it as "It is an organized structured processing of the financial data available about an organization in order to obtain from it 
information that is used in the decision-making process and in evaluating the performance of commercial and financial organization in the past and present, also to predict what the situation will be in the future."

From the above, we find that financial analysis is based on analyzing accounting information and returning it to the activities it represented for the purposes of planning, control and decision-making.

\subsection{Financial Analysis Objectives}

The objectives of financial analysis can be limited to the following aspects: -

To identify the real financial situation of the foundation, and to know the ability of the foundation to serve its debts and its ability to borrow.

Evaluating the financial and operational policies followed, and evaluating the investment schedule in the foundation.

\subsection{Financial Analysis Tools and Methods}

In order to reach rational decisions that preserve the organization's march to achieve its objectives, the financial analyst needs to complete his analysis with appropriate technical tools - as there is no analytical tool that meets all the purposes and objectives of financial analysis - knowing that we can use more than one analytical tool to reach relevant indications.

(Alqam, 2018) The financial analysis tools are referred to as "A set of different technical means, ways and methods used by the financial analyst to gain an assessment of the different aspects of the activity of the enterprise and the weaknesses and strengths of its financial and operational processes that enable him to make the necessary comparisons and conclusions to evaluate it, and the use of a particular method (instruments) of financial analysis depends on several factors:

The goal of financial analysis: (The financial analyst's competence and experience, providing relevant financial information and data for the purpose of analysis, determining the extent and scope of financial analysis). Accordingly, financial analysis tools can be divided into:

\subsubsection{First: Vertical Analysis}

It is called the vertical analysis, and it analyzes each of the financial statements separately, so the vertical analysis is done for one year. This analysis is based on "the transformation of the absolute numbers of items in financial statements into percentages, as it is based on the comparison between figures in the financial statements that occurred in the same period. This analysis is characterized by being static, as it lacks of temporal dimension".

\subsubsection{Second: Horizontal Analysis}

Horizontal analysis is carried out by comparing the financial data contained in the financial statements of a particular facility with each other, and for a certain number of successive financial periods to determine changes and to analyze trends that occurred during time periods. In this method, historical development is analyzed. Analyzing here is based on a comparison between two years or more for the same item in the financial statements "to find out the amount and direction of change in the movement of the item, or the percentage of change over the time period - the domain of comparison".

\subsubsection{Third: Analysis Using Financial Ratios}

Analysis using financial ratios is one of the most important and oldest means of financial analysis used in the study of the financial and credit position of establishments and the judgment of the results of their actions, as this method is based on the basis that any number of financial statements does not in itself indicate anything important, and does not provide useful information, but the importance of this number appears if it is compared or attributed to other numbers. Perhaps the most important thing that helped the widespread use of financial ratios is the ease with which they are extracted and understood. And we will discuss in detail the financial ratios in the third chapter, as they are one of the variables of this study.

Financial ratios help to give meaningful indications to the data included in these lists. There are large numbers of important financial ratios, which are used to provide information that helps in making decisions and evaluating performance. The financial ratios represent a relationship between two or more items of the financial statements, and the items that are included in the derivation of financial ratios may exist on the same financial statement or on two consecutive lists. 


\subsection{Importance of Financial Ratios}

The importance of financial ratios stems from the fact that they are able to make a useful comparison between two variables, as they are interpreting the relationship between two items in a manner that provides understandable and easy-to-use information. The importance of financial ratios is highlighted in the following points: -

(Presenting meaningful and useful connotations, reviewing the trend of items in the financial statements in financial periods for the same establishment, comparing the establishment with other establishments belonging to the same sector, comparing the establishment with the approved \& standard industrial benchmarks, evaluating the establishment's performance and the performance of its management, assisting in making rational administrative decisions and identifying weaknesses and strengths in the establishment and proposing recommendations and policies to address them).

First: - Liquidity ratios are meant as: The ratios that measure the facility's ability to fulfill its short-term financial obligations. If the financial ratio is low, this means the facility's inability to pay its short-term debts, and it may face financial hardship, and if the financial ratio is high, this means that the facility is not Able to exploit funds profitably in the sense that it is detained with current assets that yield little return, so it is better for the facility's liquidity ratios to be reasonable. The liquidity ratios consist of the following: -

(Trading ratio, quick liquidity ratio, Cash ratio, net working capital, accounts receivable turnover ratio, storage period)

Second: - Profitability ratios: This ratio refers to the efficiency of management in making profits, and profits are usually used as a measure of the effectiveness of the policies pursued by the administration, and these policies are operational and financing, and it is calculated on the basis of their relationship to sales and investment. It is the outcome of the policies and decisions of the establishment in relation to liquidity and financial leverage.

\subsection{Profitability Ratios Consist of the Following}

(Gross profit margin, net profit margin, return on assets (ROA), return on equity (ROE)).

Third: - Coverage ratios (indebtedness) (capital structure): These ratios that help in the study of the financial structure of the establishment and set for each and every aspect of the financial position list, it shows the relative distribution of asset elements, as well as liabilities, are it is more significant for the study of the financing structure of the establishment, and it include two main groups, namely the leverage ratio group, and the interest rate group. Coverage ratios consist of: - (capital structure ratio, debt ratio, interest coverage ratio, long-term debt coverage ratio, property ratio).

Fourth: - Ratios of activity and effectiveness: These ratios of all kinds indicate the ability of the facility to use the resources available to it effectively and efficiently, i.e. the efficiency of the establishment in the use of its various assets or its efficiency in the investment of its fixed and current assets, and the importance of these ratios to analysts, as well as the efficiency of the performance and profitability of the establishment in the long term. Activity ratios consist of the following:

Accounts Receivable Turnover Ratio, Inventory Turnover Ratio, Average Inventory Retention Period, Accounts Payable Turnover Ratio, Average Credit Period, Total Assets Turnover).

Fifth: - Valuation ratios (Market):

These are the ratios reflected by the financial market as a result of the performance of the establishment, and it appears in the financial publications, it gives information about market price trends for shares.

Market ratios consist of the following:

(Earnings per share (EPS), ratio of market value per common share and dividend yield per share).

Using financial analysis to make investment and lending decisions.

The corporate sector in Jordan plays an important role in economic development and in the following areas:

\subsubsection{First: In the Field of Lending}

The decision taken by the Bank's Facilities Department to grant a loan is serious and sensitive because the funds granted by banks are often credit facilities that do not belong to them, but rather are the money of their depositors. Companies represented by their management are one of the entities that have given financial analysis a special importance as a tool to help them to make the lending decision. Also, analyzing the financial statements of borrowers helps in forming the appropriate framework through which the appropriate decision in lending can be taken. Due to 
the importance of analyzing financial data in the ability to identify the financial risks that the bank may face in the future, lenders do this type of analysis (credit analysis). This is in order to identify the risks expected to be faced in their relationship with borrowers, evaluate this relationship, and work on building the decisions related to it. The financial analysis provides a suitable model for credit officials in assessing the financial performance of the credit applicant and his ability to repay it.

The main objective of conducting financial analysis in making the lending decision from the bank's point of view is:

Evaluate the financial and cash position of the credit applicant.

Financial analysis helps in evaluating the operational performance of a credit applicant by evaluating the impact of his investment and financing decisions.

Financial analysis helps the credit department in a commercial bank to set its policy and objectives, which provides accuracy in developing the necessary credit plan.

The client's ability to pay his obligations due to the bank, the client's ability to ensure profitability, and the most important $\&$ focused on is whether the profits are a reflection of repetitive operational processes.

\subsubsection{Second: In the Field of Investment}

Financial analysis is one of the main sources that investors rely on to provide this information by extracting it from the information contained in the financial statements and other information available about the companies subject to analysis, that the financial data do not reflect the real reality and the financial performance of the establishment, such as the reputation of the management, the quality of the product, the market share of the establishment and criteria for appointing employees ... etc. And the importance of using financial analysis tools is to interpret the analysis of these data, and to convert it from raw financial data to financial data with economic and financial connotations that can be relied upon in making an investment decision.

\section{Research Methodology}

The study community consists of only two categories, namely, the financial intermediaries category at the Amman Stock Exchange (ASE), to denote the investors category, who are (60) Nos. of brokers, and the other category, the lenders category, which represent the employees of the credit departments of Jordanian banks in the Amman region, who are (50) Nos. of employees. According to the table (Sekaran, 2003), the least representative sample of brokers consists of (52) Nos., and the least representative sample of credit officers in banks consists of (44) Nos. The surveys were distributed in a comprehensive manner targeting all community members, but the sample analyzable was (55) Nos. for mediators and (45) Nos. for credit departments employees.

Statistical methods used:

Measures of central tendency and dispersion are represented by arithmetic means and standard deviations.

Simple regression analysis.

Stability test for resolution (alpha reliability score) Reliability test (Alpha).

The (Cronbach alpha) test was used to measure the stability of the measuring instrument, and Table 1 shows the results.

Reliability measurement (2) Kronbach alpha coefficients.

Table 1

\begin{tabular}{ll}
\hline Paragraphs & Kronbach Alpha Coefficient \\
\hline Profitability ratios & 0.737 \\
\hline Market ratios & 0.774 \\
\hline Liquidity ratios & 0.759 \\
\hline Debt ratios & 0.775 \\
\hline Decision-making process & 0.757 \\
\hline Overall performance & 0.910 \\
\hline
\end{tabular}


The results showed that all variable paragraphs achieved a stability factor value higher than (0.7), which is the lowest acceptable value for paragraph stability (Al-Qahtani, 2015), and the total stability value of the survey value was (0.910).

First: Demographic characteristics of the study sample:

The percentage of males surpassed females for each of the financial intermediaries and credit officers in banks, and reached $(80 \%)$ for middlemen, $(60 \%)$ for credit officers. The difference may be due to the difficult nature of the work of financial intermediaries. As for academic qualification, the vast majority of both groups are holders of a bachelor's degree, which is an indication of interest in employing holders of university qualifications. And it raises the attention that $10 \%$ of the credit staff WERE PhD holders, and this reflects the banks interest in recruiting those with higher academic qualifications. With regard to the scientific major, the percentage for both categories of accounting major converged, with more than $50 \%$.

And $\mathrm{N}$ = financial ratios analysis. The results showed that those with 3-5 years of experience represent the highest percentage of the two categories, which is (38\%) for brokers and (50\%) for credit officers.

Second: - The results of the study on the use of financial ratios:

The arithmetic and standard deviation have been extracted to answer the first study question, what are the financial ratios that both investors and lenders focus on when making investment or lending decisions?

Table 2. The results of the calculation scoring of financial ratios

\begin{tabular}{llllllll}
\hline \multirow{2}{*}{ Number } & Type of financial ratio & \multicolumn{2}{l}{ Broker category } & \multicolumn{4}{l}{ Category of credit officers } \\
\cline { 3 - 8 } & $\begin{array}{l}\text { Standard } \\
\text { deviation }\end{array}$ & $\begin{array}{l}\text { Average } \\
\text { arithmetic }\end{array}$ & Order & $\begin{array}{l}\text { Standard } \\
\text { deviation }\end{array}$ & $\begin{array}{l}\text { Average } \\
\text { arithmetic }\end{array}$ & Order \\
\hline 1 & Profitability ratios & 0.271 & 4.87 & 1 & 0.369 & 4.15 & 3 \\
\hline 2 & Market ratios & 0.425 & 4.36 & 2 & 0.413 & 3,83 & 4 \\
\hline 3 & Liquidity ratios & 0.309 & 4.13 & 3 & 0.363 & 4.40 & 2 \\
\hline 4 & Debt ratios & 0.288 & 4.04 & 4 & 0.253 & 4.58 & 1 \\
\hline
\end{tabular}

From Table 2 it becomes clear that there are differences in the extent of interest of both financial intermediaries and credit officers in making the decision whether it is investment or lending. With regard to financial intermediaries, the biggest focus is on the profitability ratio, as it achieved a high arithmetic average (4.87), and the least important is the debt ratio with an arithmetic average (4.04). With the knowledge that the results showed that all types of financial ratios are important to brokers. With regard to credit officers, it was found that all financial ratios are important, but the debt ratio is the most with an arithmetic average (4.58), and the lowest belongs to the market ratio (3.83). There is a difference in the interest of the two categories of credit officers and brokers, as the brokers represent the category of investors "Owners" who are interested in increasing the value of their investments "market ratios". This may be through entering into high-profit projects and in return, high-risk projects, while the interest of the lenders is to achieve profit with a minimum risk, which guarantees the repayment of the value of loans, as lenders are more sensitive and vulnerable than owners when exposed to risks. Therefore, the priority for lenders is to the ratios that reflect the company's ability to fulfill its obligations and face the risks of default.

Hypothesis testing:

First - testing the first hypothesis:

H01: There is no statistically significant effect at $(0.05 \geq \alpha)$ of the financial analysis ratios in making investment decisions among investors.

To test the hypothesis, a simple linear regression test was used, and Table (3) shows the results of the test. 
Table 3. The results of the simple linear regression test for the first hypothesis

\begin{tabular}{llllllll}
\hline $\begin{array}{l}\text { Dependent } \\
\text { variable }\end{array}$ & $\begin{array}{l}\mathrm{R} \\
\text { Correlation } \\
\text { coefficient }\end{array}$ & $\begin{array}{l}\text { R2 } \\
\text { Selection } \\
\text { coefficient }\end{array}$ & $\begin{array}{l}\text { Independent } \\
\text { variable }\end{array}$ & $\mathrm{B}$ & $\mathrm{t}$ & $\mathrm{t}$ & $\mathrm{Sig}$ \\
Tabular & Calculated & $\begin{array}{l}\text { Level of } \\
\text { significance }\end{array}$ \\
\hline $\begin{array}{l}\text { Making an } \\
\text { investment } \\
\text { decision }\end{array}$ & 0.725 & 0.526 & $\begin{array}{l}\text { Financial } \\
\text { analysis } \\
\text { ratios }\end{array}$ & 0.786 & 2.009 & 21.634 & 0.000 \\
\hline
\end{tabular}

The tabular $\mathrm{t}$ value was extracted to compare it with the calculated $\mathrm{t}$ value, and it was found that the calculated $\mathrm{t}$ value (21.6344) is greater than its tabular value of (2.009), and that the level of significance of the test is less than the level of significance adopted in the study and its value is (0.05), and from which we reject the first hypothesis and we accept the alternative that there is a statistically significant effect of the financial analysis ratios on investment decision-making among investors. Also, there is a correlation relationship between the variable financial ratios and investment decision making, and the value of $\mathrm{R}$ was inferred, and the value of the correlation coefficient $=0.725$, which indicates a strong positive relationship between the two variables because it is greater than (0.5) (Cohen, 1988). The results proved that there is an interpretive ability of the financial analysis ratios in making the investment decision, its value $(52.6 \%)$, and it was inferred from the value of the determination coefficient $\mathrm{R} 2=0.526$. It is inferred from the value of $\mathrm{B}$ that if the calculation of financial ratios is improved and updated as one unit, the investment decision-making process will improve with a value of $=0.786$

Second: - The second hypothesis test:

H02: There is no statistically significant effect at $(0.05 \geq \alpha)$ for financial analysis ratios on lending decision-making among lenders.

To test the hypothesis, a simple linear regression test was used, and Table (4) shows the results of the test.

Table 4. The results of the simple linear regression test for the second hypothesis

\begin{tabular}{llllllll}
\hline $\begin{array}{l}\text { Dependent } \\
\text { variable }\end{array}$ & $\begin{array}{l}\text { R Correlation } \\
\text { coefficient }\end{array}$ & $\begin{array}{l}\text { R2 } \\
\text { Selection } \\
\text { coefficient }\end{array}$ & $\begin{array}{l}\text { Independent } \\
\text { variable }\end{array}$ & $\mathrm{B}$ & $\begin{array}{l}\mathrm{t} \\
\text { Tabular }\end{array}$ & $\begin{array}{l}\mathrm{t} \text { Calculated } \\
\text { Cignificance }\end{array}$ \\
\hline $\begin{array}{l}\text { Decision } \\
\text { lend }\end{array}$ & 0.749 & 0.557 & $\begin{array}{l}\text { Financial } \\
\text { analysis } \\
\text { ratios }\end{array}$ & 0.812 & 1.96 & 23.548 & 0.000 \\
\hline
\end{tabular}

The tabular value of $\mathrm{t}$ was extracted to compare it with the calculated $\mathrm{t}$ value, and it was found that the calculated $\mathrm{t}$ value (23.54) is greater than its tabular value of (2.021), and that the level of significance of the test is less than the level of significance adopted in the study and its value is (0.05), from which we reject the second hypothesis And we accept the alternative that there is a statistically significant effect of the ratios of financial analysis on lending decision-making for lenders. Also there is a correlation relationship between the variable financial ratios and the decision-making lending and the value of $\mathrm{R}$ was inferred, and the value of the correlation coefficient $=0.749$, which indicates a strong positive relationship between the two variables because it is greater than (0.5) (Cohen, 1988). The results proved that there is an interpretive ability of the financial analysis ratios in making the lending decision, its value $(55.7 \%)$, and it was inferred from the value of the determination factor $\mathrm{R} 2=0.557$. It is inferred from the value of B that if the calculation of the financial ratios as one unit is improved and updated, the lending decision will improve with a value of $=0.812$

\section{Results and Conclusion}

The analysis of financial ratios and their identification of all kinds affect the investors 'decision when making an investment decision, and the decision of the investors is greatly affected by the analysis of the financial ratios, and the financial ratios contribute approximately (53\%) when making the decision. for investors, investment decision-making is closely related to the accuracy of the financial ratios analysis. The clearer the financial ratios and accurately analyzed, the faster the decision-making effect increases. 
Credit officers rely on analyzing financial ratios when making the lending decision and the decision is greatly affected when examining and analyzing the types of financial ratios. The analysis and identification of financial ratios of all kinds contribute to the decision-making of lending by approximately (56\%). In addition, making a lending decision is closely related to an analysis of the types of financial ratios, so the more accurate and clear the analysis of financial ratios is, and being accessible by credit officers, the possibility of making a lending decision increases.

Investors rely on several types of financial ratios in making an investment decision, but more attention is given to the profitability ratio, and less to the debt ratio. On the other hand, credit officers differ with investors in the degree of importance of the types of financial ratios, so that the greatest interest is in the debt ratio, and the least to the market ratio; however, credit officers are interested in all types of financial ratios analysis and rely on them in making the lending decision.

\section{Recommendations}

In light of the economic conditions in Jordan, we need several studies in this field, especially that we are a developing country that needs investments and depends on loans, but we have to choose what suits us based on financial ratios, as preparing financial ratios does not require skill and ability, but rather you need to interpret the results in a way that leads you to make a decision. It is appropriate to invest or borrow and perhaps choose and interpret the financial ratios that distinguish between the competent analyst and the inefficient analyst, The Jordanian government has been interested in investing through the establishment of the Investment Authority and has given it wide powers to attract investment by presenting projects in infrastructure and promising economic projects. It is also presenting a financial study supervised by financial analysts and all that matters to us is we have the ability to clearly explain the financial ratios in a way that attracts and encourages investment and ensures its continuity And protect it We have many troubled companies and they increased in the period of the Corona epidemic, and these companies are not able to pay their debts, and they must either reschedule these debts from lenders and creditors or settle these debts permanently. For loss, including lowering the interest rate, therefore, choosing and a clear interpretation of the financial ratios helps many companies make the appropriate decision to borrow so that they are able to repay and maintain the continuity of these companies and give lenders confidence that their money will be paid on its due date.

The aim of the study is in light of the economic conditions that the world is going through due to the conditions of the Corona epidemic that Jordan's economy is going through, especially as a developing country, needs more investments and borrowing for infrastructure projects, creating job opportunities, reducing the poverty rate, and in order to maintain the continuation of emerging companies in the course of Its business is through choosing and interpreting the correct financial ratios in order to choose the appropriate decision for investment or borrowing

\section{References}

Abdel-Fattah, Al.-S. (2019). Financial analysis as a tool for evaluating the financial performance of industrial joint-stock companies in Palestine: A case study of pharmaceutical companies listed on the Palestine Exchange for the period between (2010-2017). Journal of Research in Islamic Sciences, 4(2). Retrieved from https://www.asjp.cerist.dz/en/article/104717

Al-Shatnawi, Al.-Q., \& Shukry, Al. (2016). The impact of using the financial analysis system in reducing the risk of financial crises on Jordanian banks and facing their current impact and predicting credit risks. Journal of Accounting, Auditing and Governance, Jerash University, 1(1). Retrieved from https://jo24.net/article/130978

Annette, H. D., \& Christopher, D. B. B. (2011). Organizational memory and empowerment. Journal of Knowledge Management, 15(5).

Barakat, S. (2018). Commercial banks use of financial ratios in financing decision-making. Master's Thesis, University of Oum El Bouaghi, Algeria. Retrieved from http://bib.univ-oeb.dz:8080/jspui/handle/123456789/4664

Bikaybah, A. (2019). The Role of Financial Analysis in Financial Decision Making. MA Thesis, University of Mohamed Khoudair Issacha, Algeria. $\quad$ Retrieved from http://archives.univ-biskra.dz/bitstream/123456789/13098/1/berekbia_mohamed_ali.pdf

Cohen, J. W. (1988). Statistical power analysis for the behavioral science (2nd ed.).

Mahmoud, Al.-K. (2013). Financial Analysis Using Financial Data (6th ed.). Wael Publishing House, Amman, Jordan.

Mufleh, A. (2014). Introduction to financial management and financial analysis (1st ed.). Arab Society Library for 
Publishing and Distribution, Jordan.

Muhammad, A. (2018). Financial statement analysis for the purposes of decision-making and performance evaluation (1st ed.). Amman, Jordan.

Muhammad, Al.-A. (2018). Using financial analysis methods in evaluating the performance of pharmaceutical companies listed on the Amman Financial Market: a comparative study. Islamic Entrepreneurship Journal, 3(3), 101-110. Retrieved from https://search.emarefa.net/en/viewer/renderPdf?docId=902935

Muhammad, F. (2020). Financial analysis tools to evaluate the efficiency of credit and investment decisions Al-Shorouk (Nov 2020). Retrieved from https://al-sharq.com/opinion/18/05/2014

Muhammad, M. (2016). Recent trends in financial and credit analysis (3rd ed.). Wael Publishing House, Amman, Jordan.

Mutasim, Al.-H. (2016). The Extent of Using Financial Ratios in Financing Decision Making An Analytical Study on Palestinian Islamic Banks. Master Thesis, Islamic University, Gaza-Palestine. Retrieved from https://www.mobt3ath.com/uplode/book/book-25167.pdf

Rima, H. (2018). The Impact of Financial Information on Investment Decision-Making in the Amman Financial Market. Journal of Financial and Administrative Studies, (9).

Saad, Al.-Q. (2015). Applied statistics: basic concepts and tools of statistical analysis. General Administration of Printing and Publishing, Riyadh.

Sekaran, U. (2003). Research methods for business (4th ed.). New York: John Willey \& Sons Inc.

Shaheen, B. (2019). The Main Factors That Determine the Credit Decision in the Palestinian Commercial Banks Master's degree in management Business, Faculty of Graduate Studies. Hebron University 2019. Retrieved from http://dspace.hebron.edu/jspui/bitstream/123456789/763/1

\section{Copyrights}

Copyright for this article is retained by the author(s), with first publication rights granted to the journal.

This is an open-access article distributed under the terms and conditions of the Creative Commons Attribution license (http://creativecommons.org/licenses/by/4.0/). 